\title{
Development of E-Book Learning Media in Drawing Manswear Sewing Pattern in Fashion Study Program
}

\author{
Halida Hanim ${ }^{1}$, Farihah ${ }^{2}$, Nurmaya Napitu ${ }^{3}$, Surani ${ }^{4}$ \\ Prodi Pendidikan Tata Busana, Program Sarjana, Universitas Negeri Medan ${ }^{1,2,3,4}$ \\ halidahanimp@gmail.com
}

\begin{abstract}
This study aims to develop e-book learning media as a teaching material patterns create in Fashion Education Study Program, Faculty of Engineering, State University of Medan, as a good learning resource and can function properly with effective results and can be used as a learning media. The research design used in this study is R\&D. This research is used to develop or validate products that be used in education and learning. The research and development methods are research methods that be used to produce certain products, and to test the effectiveness of the products. The development of educational products in this research is e-book media development. This model has several stages: potential and problems, data collection, product design, product validation, trial use, product revision, product trial, design revision, product revision, mass production. The test subjects consisted of material experts, media experts, and students. The data about the quality of these development products was collected by a questionnaire. Every data that be collected were analyzed using qualitative descriptive analysis techniques.
\end{abstract}

Keywords: E-Book, Manswear Sewing Pattern, Undergraduate Students of Fashion.

\section{Introduction}

Developments in the field of science and technology (science and technology) currently affect various aspects of human life, including in the world of education. The development of science and technology encourages efforts to renew the use of technology in the learning process. The fashion study program of the Faculty of Engineering UNIMED is one of the vocational education institutions that prepares graduates who are ready to work according to the area of expertise learned, with a vision and mission to produce professional human resources who have competitiveness, noble character and care for the environment and are accepted by the community. To prepare graduates who are ready to work in the fashion study program, they have many practical subjects, one of which is fundamental is Men's Clothing courses. Men's clothing is a course given to fourth semester students because it is a basic course that must be known and mastered by every student.

One obstacle in the learning process in the classroom, especially in the Men's Clothing course, is learning centered on lecturers, as a result of students become less independent. Another obstacle is its limitations literature/ material/ material/ media used by lecturers about drawing men's clothing patterns. 
Some of the problems above are important and must immediately utilize computer or other electronic devices owned by students as a medium for learning itself, because the media can facilitate students in accepting lessons delivered by lecturers.

E-books take advantage of technological advances in learning, e-books created can be stored in devices such as mobile phones, laptops or iPads, so students can carry subject matter everywhere and are no longer burdened with printed books, in other words the use of e-books can more flexible compared to printed books.

Another advantage of e-books can be developed not only in the form of text, but can include pictures, animations, music videos and sounds so that it is more interesting than ordinary textbooks. Moreover, for practical courses, students can be facilitated by e-books because in ebooks videos can be included such as work steps for drawing patterns.

\section{Research Method}

The development model used in this study is a 3D form that is Define, Design and Develop. This model is a research method used to develop or validate products used in education and learning. The 4D research model stands for Define, Design, Development and Dissemination. The development of e-book learning media in the Men's Clothing course is carried out by research and development methods (research and development). Research and development methods are research methods used to produce certain products, and discover the effectiveness of these products [1].

Borg and Gall in Sugiyono [1] stated that, research and development (R\&D) is research used to develop or validate products used in education and learning. The development of educational products in this research is in the form of e-book media development.

\section{Development Procedure}

In this research and development product that will be produced is an e-book learning media for drawing men's clothing patterns. In designing media products, a step that must be taken beforehand is to outline media programs.

\section{Block diagram of making media}

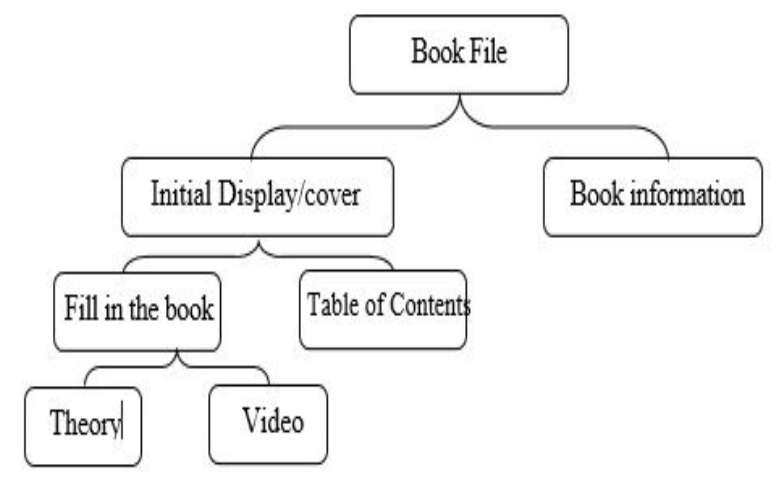




\section{Data Collection Technique}

Data collection techniques in this study were conducted using a questionnaire. Questionnaire is a data collection technique that contains questions or statements submitted in writing to a person or group of people to get the answers or responses and information needed by researchers.

\section{Research Instruments}

In this study including quantitative research that is collecting data then analyzed quantitatively using descriptive statistics. The instrument used in this study was a closed questionnaire in which the respondent gave a choice of answers by putting a check mark (pada) in the answer column provided. The instrument is a closed questionnaire aimed at experts namely material experts and media experts, and given to students.

\section{Data Analysis Technique}

This research focuses more on the effectiveness of products designed as E-Books to create men's clothing patterns, so that the data are analyzed properly to analyze data from the questionnaire, the following steps are carried out:

1. Questionnaire that has been filled in by the respondent, checking the completeness of the answers then arranged according to the respondent's method,

2. Quantitative questions by giving a score according to predetermined weights,

3. Loading data tabulation

4. Calculate the percentage of each sub variable with the following formula:

$\mathrm{P}=\mathrm{F} / \mathrm{N} \times 100$

\section{Result and Discussion}

The initial process of research and development is the potential seen from the existence of facilities and carrying capacity that can be developed for electronic-based media, internet networks (wifi), so the problem is the deviation between what is expected and what happens.

Based on the results of the analysis of the needs of lecturers and students, it can be concluded that supporting learning by using E-Book learning media is needed. Then the results of interviews from lecturers who support men's fashion courses, drawing men's clothing patterns are difficult to find learning media that motivates students. Therefore, E-Book learning media is needed to draw male fashion patterns and this media is easily accessed anywhere and anytime by students.

A series of development results have been carried out, for that the next step is to design and develop E-Book learning media.

\section{Product development}

At this stage the learning media developed were included in the category of strongly agree / very good with the percentage of the results of the assessment of each material expert $83 \%$ strongly agreed / very good, $87.14 \%$ of the media experts strongly agreed / very good, for the results of the first stage test $63,3 \%$, the results of the second phase trial $79.25 \%$, and field trials $89.25 \%$. 


\section{Product effectiveness}

At this stage the multimedia-based E-Book learning media developed effectively are used as learning media. Based on the results of student responses to effectiveness trials conducted at the field trial stage obtained an assessment with very good criteria with an average percentage of $89.25 \%$ and lecturer responses were rated very well with an average percentage of $93.33 \%$.

\section{Conclusions}

That the E-Book media is really needed in men's fashion courses, especially in making men's clothing patterns. As teaching material that supports the learning process, this E-Book learning media is a media product to help the process of delivering learning in particular making patterns so that students are actively involved in the learning process.

\section{References}

[1] Sugiyono. Metode Penelitian Pendidikan Pendekatan Kuantitatif Kualitatif dan R\&D. Bandung: Alfabeta. (2012)

[2] Arsyad, A. Media Pembelajaran. Jakarta: Rajawali Pers. (2011)

[3] Eka, Wahyu P.S. Busana Pria. Klaten. PT Intan Sejati. (2017)

[4] Hanafiah \& Suhana. Konsep Strategi Pembelajaran. Bandung: Refika Aditama. (2010)

[5] Iskandar wiryokusumo. Dasar-Dasar Pengembangan Kurikulum. Jakarta: Bumi Aksara Metari, D dkk. (2018). Pengembangan Media Pembelajaran E-book Berdasarkan Hasil Riset Elektroforesis 2-d Untuk Mengukur Kemampuan Berfikir Kreatif Mahasiswa. Journal of science education, 2(2), 131-134. (2011)

[6] Nugraha, D.A \& Wasis. Pengembangan Media E-book Interaktif Billingual Pada Materi Pokok Kalor Untuk SMA Semester IV. Jurnal inovasi pendidikan fisika (JIPF), 3(1), 1-7. (2014)

[7] Prihatin, eka. Dosenu Sebagai Fasilitator. Bandung: Karsa Mandiri Persada. (2008)

[8] Sadiman, A dkk. Media Pendidikan. Jakarta: Rajawali Pers. (2012)

[9] Sudjana N dan Riva'i A. Media Pengajaran. Bandung: Sinar Baru Algesindo. (2010)

[10] Supriyadi. Simulasi Digital SMK Semester IV. Jakarta: Kementrian Pendidikan dan Kebudayaan. (2013)

[11] Suryani. Strategi Belajar Mengajar. Yogyakarta: Ombak. (2012)

[12] Susilana, R dan Riyana, C. Media Pembelajaran. Bandung: Wacana Prima. (2016) 